\title{
Evaluation of Brinjal (Solanum melongena L.) Genotypes for Growth and Yield Parameters
}

\author{
Hadassah Chinthagunti", D.A. Sarnaik and Dhananjay Sharma \\ Department of Horticulture, College of Agriculture, Indira Gandhi Krishi Viswavidhyalaya, \\ Raipur - 492 012, Chhattisgarh, India \\ *Corresponding author
}

\begin{abstract}
A B S T R A C T
A comparative study on 16 brinjal genotypes ( 15 hybrids and 1 open pollinated variety) for growth and yield attributing parameters was conducted at Indira Gandhi Krishi

Keywords

Brinjal, Evaluation, Growth, Yield

Article Info

Accepted:

24 November 2018

Available Online:

10 December 2018 Viswavidhyalaya, Raipur, during rabi 2012-2013.The three tallest hybrids were 2012/BRRHYB-5 and 2012/BRRHYB-7 which are also the hybrids with most number of branches 120 days after transplanting. The fruits of Kashi Sandesh and Swarna Mani Black had thickest pericarp and are also statistically superior in fruit girth. In the present findings, the higher pericarp thickness may be due to the higher fruit girth. Pusa Hybrid-6 had maximum TSS (5.2\%). The maximum fruit weight was observed in 2012/BRRHYB$3(267.08 \mathrm{~g})$ while minimum fruit weight was observed in 2011/ BRRHYB-7 (25.2 g). 2011/BRRHYB-7 and 2012/BRRHYB-4 were hybrids with high number of fruits per plant and are also the hybrids with smallest fruits in terms of fruit girth and pericarp thickness. Maximum yield in 2012/ BRRHYB-7 (472.92 q/ha) was due to higher weight of fruit (252.25 g) and yield per plant (2.27 kg), whereas in 2012/ BRRHYB-4 higher yield per hectare (446.61 q/ha) was attributed to its higher number of fruits per plant (44.73) and yield per plant $(2.60 \mathrm{~kg})$ even though it showed less individual fruit weight $(88.42 \mathrm{~g})$.
\end{abstract}

\section{Introduction}

The brinjal or eggplant (Solanum melongena L.) is one of the most popular and principal vegetable crops grown in India and other parts of the world. The cultivated brinjal is presumed to be of Indian origin with China as secondary centre of origin. It has been cultivated for many centuries in India, China, Arabia and was probably introduced into Europe during the Moorish invasion of Spain in $16^{\text {th }}$ century.
In India, brinjal is cultivated in an area of 669 thousand ha with a production of 12,400 thousand tonnes per year (Horticultural Statistics at a Glance, 2017). In view of increasing population, there is a need for increased production and productivity levels of brinjal. Further, there is high local preference for colour, shape, taste and there are specific genotypes suited for specific locality. It is not possible to have one common cultivar which may be suitable for different areas and it is therefore required to improve the locally preferred cultivars for high yield 
and adaptation or development of new hybrid combinations.

Hybrid varieties have many advantages over the local varieties. Scientific and accurate breeding programs have made it possible not only to bring out the outstanding qualities of the parent plants, but in most cases these qualities have been enhanced and new desirable characteristics added to the resultant hybrid plants. In addition to qualities like good vigor, trueness to type, heavy yields and high uniformity which hybrid plants enjoy, other characteristics such as earliness, disease resistance and good holding ability have been incorporated into most $\mathrm{F}_{1}$ hybrids. Uniform plant habit and maturity, coupled with uniformity in shape or size have made hybrid vegetables extremely suitable for commercial cultivation. Today we have many hybrid varieties available in the market, and it necessitates their evaluation to find out the best suited varieties for a particular place that fulfill the requirement of farmers and consumers of specific choice. Looking at above facts, an experiment was designed to evaluate the hybrids for growth and yield attributing parameters.

\section{Materials and Methods}

The present experiment on evaluation was conducted during the rabi season of 2012-13 at Horticulture Farm, Department of Horticulture, College of Agriculture, Indira Gandhi Krishi Viswavidyalaya, Raipur (C.G.).

Raipur is situated at the $21^{\circ} 16^{\prime} \mathrm{N}$ latitude and $81^{\circ} 36^{\prime}$ E longitude at an altitude of 289.56 meters above mean sea level. Raipur, the place of investigation, is a sub-humid region. It comes under the seventh agro-climatic zone of the country, i.e. eastern plateau and hills. The soil of the experimental site is clay with average fertility and drainage.
The experiment was laid out in a randomized complete block design (RCBD) with three replications comprising 16 genotypes $\left(15 \mathrm{~F}_{1}\right.$ hybrids +1 open pollinated variety).

The treatments consisted of hybrids 2011/ BRRHYB-1， 2011/ BRRHYB-2， 2011/ BRRHYB-3， 2011/ BRRHYB-4， 2011/ BRRHYB-5, 2011/ BRRHYB-7, 2012/ BRRHYB-2, 2012/ BRRHYB-3, 2012/ BRRHYB-4， 2012/ BRRHYB-5, 2012/ BRRHYB-6, 2012/ BRRHYB-7, EPH-178, Kashi Sandesh, Pusa Hybrid-6 and an open pollinated variety Swarna Mani Black.

Individual plots were observed for normal plants representing each genotype and the following observations were recorded during the crop growth period on ten randomly selected competitive plants, which were tagged in each plot of every replication. Observations were recorded on plant height (cm), number of branches per plant, fruit length $(\mathrm{cm})$, fruit girth $(\mathrm{cm})$, pericarp thickness $(\mathrm{cm})$, TSS (\%), number of fruits per plant, average fruit weight $(\mathrm{g})$, yield per plant (kg) and total yield (q/ha). The data was analyzed by adopting the standard procedure of Panse and Sukhatme (1985) and using AGRISTAT software. Wherever, the results were found significant, critical differences (CD) were computed at 5 percent level of probability to draw statistical conclusions.

\section{Results and Discussion}

\section{Growth parameters}

The results of the present investigation for growth characters are depicted in Table 1. The results showed that maximum plant height at 120 DAT was observed in 2012/ BRRHYB-5 $(67.23 \mathrm{~cm})$ which was found to be statistically at par with Swarna Mani Black $(66.9 \mathrm{~cm})$ and 2012/ BRRHYB-7 (64.47 cm) and significantly superior over the rest of the 
entries. Number of branches per plant at 120 days after transplanting ranged from 2.67 (2012/ BRRHYB-2) to 7.6 (Swarna Mani Black) with an overall mean of 4.71 . Number of branches per plant has been primarily found to be related with endogenous hormonal level and apical dominance and also influenced by genetic makeup of the treatments. High variability for number of branches per plant was reported by Muniappan et al., (2010) and Arunkumar et al., (2013).

Longest fruit length was observed in 2011/BRRHYB-5 (12.06 cm) which was found to be statistically similar to with 2012/ BRRHYB-4 (11.93 cm) and 2011/ BRRHYB$3(11.87 \mathrm{~cm})$. The shortest fruit length was observed in EPH-178 $(6.3 \mathrm{~cm})$. The fruits of Kashi Sandesh had thickest pericarp (1.27 $\mathrm{cm})$ and are also statistically superior in fruit girth $(26.27 \mathrm{~cm})$. In the present findings, the higher pericarp thickness may be due to the higher fruit girth. Varieties with greater fruit girth recorded greater pericarp thickness and varieties with less fruit girth recorded lesser pericarp thickness. The findings are in accordance with those reported by Dubey (2012). The average TSS ranged from $4 \%$ (2011/ BRRHYB-1, 2011/ BRRHYB-2 and 2012/ BRRHYB-6) to $5.2 \%$ (Pusa Hybrid-6) with an overall mean of $4.46 \%$.

The fruits of hybrid 2012/ BRRHYB-3 had maximum weight of $267.08 \mathrm{~g}$ which was found to be statistically similar to 2012/ BRRHYB-7 (252.25 g), 2012/ BRRHYB-6 (250.17 g) and 2011/ BRRHYB-3 (230.75 g) and significantly superior over the rest of the treatments. The minimum fruit weight was observed in 2011/ BRRHYB-7 (25.2 g) which was found to be statistically at par with 2012/ BRRHYB-5 (68.42 g). The increase in fruit weight in the present findings was attributed to higher fruit girth and pericarp thickness as observed in 2012/ BRRHYB-3 (26.49cm,
$0.9 \mathrm{~cm}), \quad 2012 / \quad$ BRRHYB-7 $\quad(25.83 \mathrm{~cm}$, $1.09 \mathrm{~cm})$ and 2012/ BRRHYB-6 $(25.27 \mathrm{~cm}$, $1.06 \mathrm{~cm})$ respectively. Hybrid 2011/ BRRHYB-7 had maximum number of fruits per plant (52.8) while, hybrid 2011/ BRRHYB-3 had minimum number of total fruits per plant. The overall mean was 17.40 fruits per plant.

\section{Yield parameters}

The results of the present investigation for yield parameters are depicted in Table 2. The results showed that total fruit yield per plant ranged from $1.03 \mathrm{~kg}$ (2011/ BRRHYB-7) to $2.60 \mathrm{~kg}$ (2012/ BRRHYB-4). In entries 2012/ BRRHYB-6 (2.50 kg) and 2012/ BRRHYB-7 $(2.27 \mathrm{~kg})$ higher fruit yield per plant was attributed to the factors that they showed higher fruit girth, fruit weight and number of fruits per plant. The results are in concordance with those of Prabhu et al., (2008) and Dharwad et al., (2009).

The maximum yield per hectare was observed in 2012/ BRRHYB-7 (472.92 q) which was found to be statistically at par with 2012/ BRRHYB-4 (446.61 q) and EPH-178 (418.91 q). The minimum yield per hectare was observed in 2011/ BRRHYB-7 (130.64 quintals) which was found to be statistically similar to 2011/ BRRHYB-3 (167.96 q) and 2011/ BRRHYB-4 (184.72 q).

Yield is a complex character and is determined by many genes and is largely influenced by environmental conditions. The varietal differences always play an important role in the determination of yield. In the present study data regarding yield per plant as well as per hectare showed significant differences among the treatments. The yield being a polygenic trait is a result of component characters like number of fruits per plant and fruit weight. 
Table.1 Performance of brinjal genotypes for growth characters

\begin{tabular}{|c|c|c|c|c|c|c|}
\hline Treatments & $\begin{array}{l}\text { Plant height } \\
\quad(\mathrm{cm})\end{array}$ & $\begin{array}{l}\text { Number of } \\
\text { branches }\end{array}$ & $\begin{array}{l}\text { Fruit length } \\
\qquad(\mathrm{cm})\end{array}$ & $\begin{array}{l}\text { Fruit girth } \\
\qquad(\mathrm{cm})\end{array}$ & $\begin{array}{l}\text { Pericarp } \\
\text { thickness } \\
\quad(\mathrm{cm})\end{array}$ & TSS ( $\%)$ \\
\hline 2011/ BRRHYB-1 & 46.57 & 3.47 & 8.69 & 25.36 & 0.78 & 4.00 \\
\hline 2011/ BRRHYB-2 & 51.27 & 3.73 & 9.08 & 26.71 & 0.80 & 4.00 \\
\hline 2011/ BRRHYB-3 & 53.97 & 3.60 & 11.87 & 24.63 & 0.90 & 4.43 \\
\hline 2011/ BRRHYB-4 & 54.13 & 4.53 & 9.25 & 24.20 & 0.69 & 4.93 \\
\hline 2011/ BRRHYB-5 & 60.90 & 3.60 & 12.06 & 22.87 & 0.79 & 4.30 \\
\hline 2011/ BRRHYB-7 & 41.97 & 3.60 & 8.06 & 14.37 & 0.46 & 4.87 \\
\hline 2012/ BRRHYB-2 & 41.70 & 2.67 & 8.31 & 19.11 & 0.64 & 4.80 \\
\hline 2012/ BRRHYB-3 & 57.20 & 5.47 & 9.39 & 26.49 & 0.9 & 4.40 \\
\hline 2012/ BRRHYB-4 & 53.83 & 5.60 & 11.93 & 14.79 & 0.63 & 4.80 \\
\hline 2012/ BRRHYB-5 & 67.23 & 6.73 & 7.54 & 14.91 & 0.57 & 4.33 \\
\hline 2012/ BRRHYB-6 & 55.17 & 5.07 & 9.95 & 25.27 & 1.06 & 4.00 \\
\hline 2012/ BRRHYB-7 & 64.47 & 6.60 & 9.63 & 25.83 & 1.09 & 4.13 \\
\hline EPH-178 & 56.67 & 5.80 & 6.3 & 14.87 & 0.46 & 4.10 \\
\hline Kashi Sandesh & 44.97 & 4.07 & 9.57 & 26.27 & 1.27 & 4.40 \\
\hline Pusa Hybrid-6 & 54.30 & 3.20 & 8.50 & 23.33 & 0.51 & 5.20 \\
\hline $\begin{array}{l}\text { Swarna Mani } \\
\text { Black }\end{array}$ & 66.90 & 7.60 & 7.71 & 24.92 & 1.23 & 4.60 \\
\hline Mean & 53.20 & 4.71 & 9.24 & 22.12 & 0.80 & 4.46 \\
\hline $\operatorname{SEm} \pm$ & 2.10 & 0.45 & 0.21 & 0.60 & 0.08 & 0.20 \\
\hline CD & 6.07 & 1.29 & 0.62 & 1.72 & 0.23 & 0.57 \\
\hline CV \% & 6.69 & 16.4 & 4.02 & 4.67 & 17.25 & 7.72 \\
\hline
\end{tabular}


Table.2 Yield parameters of the different brinjal genotypes

\begin{tabular}{|c|c|c|c|c|}
\hline Treatments & Fruit weight (g) & $\begin{array}{l}\text { Number of fruits } \\
\text { per plant }\end{array}$ & $\begin{array}{l}\text { Fruit yield per plant } \\
\qquad(\mathrm{kg})\end{array}$ & Yield per ha (q) \\
\hline 2011/ BRRHYB-1 & 173.75 & 7.67 & 1.03 & 203.55 \\
\hline 2011/ BRRHYB-2 & 184.33 & 9.33 & 1.38 & 205.14 \\
\hline 2011/ BRRHYB-3 & 230.75 & 7.20 & 1.25 & 167.96 \\
\hline 2011/ BRRHYB-4 & 172.18 & 9.60 & 1.56 & 184.72 \\
\hline 2011/ BRRHYB-5 & 174.43 & 9.60 & 1.38 & 238.01 \\
\hline 2011/ BRRHYB-7 & 25.20 & 52.80 & 1.03 & 130.64 \\
\hline 2012/ BRRHYB-2 & 120.07 & 15.73 & 1.39 & 293.5 \\
\hline 2012/ BRRHYB-3 & 267.08 & 8.60 & 1.67 & 324.44 \\
\hline 2012/ BRRHYB-4 & 88.42 & 44.73 & 2.60 & 446.61 \\
\hline 2012/ BRRHYB-5 & 68.42 & 27.27 & 1.64 & 280.71 \\
\hline 2012/ BRRHYB-6 & 250.17 & 11.07 & 2.50 & 373.52 \\
\hline 2012/ BRRHYB-7 & 252.25 & 11.60 & 2.27 & 472.92 \\
\hline EPH-178 & 71.83 & 32.3 & 2.06 & 418.91 \\
\hline Kashi Sandesh & 217.83 & 11.67 & 1.85 & 379.33 \\
\hline Pusa Hybrid-6 & 174.25 & 8.80 & 1.43 & 220.35 \\
\hline $\begin{array}{l}\text { Swarna Mani } \\
\text { Black }\end{array}$ & 156.33 & 10.47 & 1.89 & 278.26 \\
\hline Mean & 164.20 & 17.40 & 1.68 & 288.66 \\
\hline SEm \pm & 17.32 & 1.73 & 0.17 & 30.67 \\
\hline CD & 50.04 & 4.99 & 0.49 & 88.58 \\
\hline CV \% & 18.28 & 17.18 & 17.34 & 18.40 \\
\hline \multicolumn{5}{|c|}{$\begin{array}{l}\text { whereas in 2012/ BRRHYB-4 higher yield } \\
\text { per hectare ( } 446.61 \mathrm{q} / \mathrm{ha}) \text { was attributed to its } \\
\text { higher number of fruits per plant }(44.73) \text { and } \\
\text { yield per plant }(2.60 \mathrm{~kg}) \text { even though it } \\
\text { showed less individual fruit weight }(88.42 \mathrm{~g}) \text {. } \\
\mathrm{F}_{1} \text { hybrid } 2011 / \mathrm{BRRHYB}-7 \text { registered }\end{array}$} \\
\hline
\end{tabular}


minimum yield per hectare (130.64 q/ha) albeit it gave maximum number of fruits per plant (52.8) which is due to the less weight of fruit $(25.2 \mathrm{~g})$ and yield per plant $(1.03 \mathrm{~kg})$. Similar results were reported by Thangamani and Jhansirani (2012). Taking the above results into consideration, the hybrids 2012/ BRRHYB-7 (472.92 q/ha) and 2012/ BRRHYB-4 (446.61 q/ha) can be suggested for cultivation in the Raipur plains.

\section{References}

Arunkumar, B., Kumar, S.V.S., Prakash, J.C. 2013. Genetic variability and divergence studies in brinjal (Solanum melongena L.). Bioinfolet, 10(2b): 739-744.

Dharwad, N.A., Salimath, P.M. and Patil, S.A. 2009. Association and path coefficient analysis in elite germplasm lines of brinjal (Solanum melongena L.). Karnataka J. of Agri. Sci., 22(5):965-966.

Dubey, Akhilesh, 2012. Genetic variability, correlation and path coefficient analysis for fruit yield and its contributing characters in brinjal hybrids (Solanum melongena L.). M.Sc. (Ag.) Thesis. IGKV, Raipur (C.G.). 73-77.

Horticultural Statistics at a Glance, 2017. Ministry of Agriculture and Farmers Welfare, Government of India

Muniappan, K., Saravanan, K. and Ramya, B. 2010. Studies on genetic divergence and variability for certain economic characters in eggplant (Solanum melongena L.). Electronic J. Plant Breeding, 1(4): 462-465.

Panse, V.G. and Sukhtme, P.V. 1985 Statistical Methods for Agricultural Workers. ICAR, New Delhi, 145-155.

Prabhu M., Natrajan, S. and Veeraragavathatham, D. 2008. Correlation and path coefficient analysis in eggplant (Solanum melongena L.). Indian J. of Agri. Res., 42(3): $232-234$.

Thangamani, C. and Jhansirani, P. 2012. Correlation and path coefficient analysis studies on yield and attributing characters in brinjal (Solanum melongena L.). Electronic J. of Plant Breeding, 3(3): 939-944.

\section{How to cite this article:}

Hadassah Chinthagunti, D.A. Sarnaik and Dhananjay Sharma. 2018. Evaluation of Brinjal (Solanum melongena L.) Genotypes for Growth and yield Parameters. Int.J.Curr.Microbiol.App.Sci. 7(12): 3095-3100. doi: https://doi.org/10.20546/ijcmas.2018.712.354 